\title{
The Emerging Trend of 'Expat-preneurs': A Headache for the Pre-existing Ethnic Entrepreneur Theories'
}

\author{
Richard Andrew GIRLING (http://orcid.org/0000-0001-6698-1022), Institute of Social Studies, University of \\ Wrocław, Poland; e-mail: richard.girling83@gmail.com
}

Emilia BAMWENDA (http://orcid.org/0000-0002-9635-4334), Institute of Social Studies, University of Wroctaw, Poland; e-mail: ebamwenda@gmail.com

\section{Artan "Gurbetçi Girişimci” Eğilimi: Öteden Beri Var Olan Etnik Girişimci Teorileri Açısından Bir Başağrısı Mı?²}

\begin{abstract}
With regards to entrepreneurship and migration, the overwhelming majority of studies have focused on entrepreneurs within the context of 'South to North' migration. This demographic is usually referred to in the literature as "ethnic entrepreneurs" (Waldinger et al., 1990) or "immigrant entrepreneurs" (Volery, 2007). More recently, a new trend is emerging: A small (but potentially significant) number of entrepreneurial migrants are emigrating away from developed economies. Differentiated from the former in terms of becoming entrepreneurs out of volition, and not necessity (Vance et al., 2016), these migrants have been labelled as "Self Initiated Expatriate entrepreneurs" (Andresen, 2014) or "expat-preneurs" (Solimine, 2015). The emerging trend of expat-preneurs poses several questions (and problems) for the existing theories surrounding ethnic entrepreneurs: Where do expat-preneurs fit into the theoretical landscape? Can the theories - created to account for ethnic entrepreneurs - also explain the behavior of expat-preneurs? This paper reviewed eight of the most prominent theories and found that all eight were created in the context of 'South to North' migration, with many of them assuming that immigrant entrepreneurs are disadvantaged. As a result, most of the theories are not - in their current state - broad enough to also account for expat-preneurs. Subsequently, most of the existing ethnic entrepreneur theories now need to be broadened to 'make room' for the phenomenon of expat-preneurs. This paper contributes to the gap in the literature surrounding expatpreneurs, which has been described as an an under-researched phenomenon (Andresen et al., 2014).
\end{abstract}

Keywords

Expat-preneurs, Self-initiated Expat Entrepreneurs, Ethnic Entrepreneurs, Immigrant Entrepreneurs, Ethnic Entrepreneurship, Lifestyle Migration, Mixed-embeddedness.

JEL Classification Codes : $\quad$ 0310, Z130, F660.

$1 \quad$ This article is the revised and extended version of the paper presented in " ${ }^{\text {th }}$ International Annual Meeting of Sosyoekonomi Society" which was held by Sosyoekonomi Society and CMEE - Center for Market Economics and Entrepreneurship of Hacettepe University, in Vienna/Austria, on October 27-28, 2017.

2 Bu makale Sosyoekonomi Derneği ile Hacettepe Üniversitesi Piyasa Ekonomisini ve Girişimciliği Geliştirme Merkezi tarafindan Avusturya'nın Viyana şehrinde, 27-28 Ekim 2017 tarihlerinde düzenlenen "Dördüncü Uluslararası Sosyoekonomi Derneği Yıllık Buluşması"nda sunulan çalışmanın gözden geçirilmiş ve genişletilmiş halidir. 
Girling, R.A. \& E. Bamwenda (2018), “The Emerging Trend of 'Expat-preneurs': A Headache

for the Pre-existing Ethnic Entrepreneur Theories”, Sosyoekonomi, Vol. 26(38), 207-219.

\section{$\ddot{O} \mathbf{z}$}

Girişimcilik ve göç ile ilgili yapılan çalışmaların büyük bir çoğunluğu "Güneyden Kuzeye" göç eden girişimciler üzerine yoğunlaşmıştır. Bu demografik özellik literatürde genellikle "etnik girişimciler" (Waldinger vd., 1990) veya "göçmen girişimciler" (Volery, 2007) olarak değerlendirilmektedir. Son dönemlerde ise yeni bir olgu ortaya çıkmıştır: Buna göre göçmen girişimcilerin az sayıda da olsa potansiyel olarak önemli bir bölümü gelişmiş ülkelerden göç etmektedir. Bu yeni göçmenler eski tür göçmenlerden farklı olarak zorunluluktan ziyade kendi istekleri ile girişimci olmaktadırlar (Vance vd., 2016). Bu yüzden bu yeni göçmenler için "Kendi iradesiyle göç eden girişimciler" (Andresen, 2014) veya "gurbetçi girişimciler / expat-preneurs" (Solimine, 2015) tabirleri kullanılmaktadır. Bu yükselen "expat-preneurs" akımı, etnik girişimcilik konusunda mevcut olan teoriler ile ilgili birkaç soru (sorun) ortaya koymaktadır: "Kendi iradesiyle göç eden girişimciler" teorik çerçevenin hangi alanına uymaktadır? Etnik girişimcilik için geliştirilen teoriler "expatpreneurs" davranışlarını açıklayabilir mi? Bu çalışmda en çok tanınan sekiz teori incelenmiş ve bu sekiz teorinin hepsinin "Güneyden Kuzeye" göç hareketleri çerçevesinde geliştirildiği ve bu teorilerin çoğunun göçmen girişimcilerin dezavantajlı oldukları varsayımına dayandığı tespit edilmiştir. Dolayısıyla, var olan teorilerin çoğu -mevcut halleriyle- "kendi isteğiyle göç eden girişimcileri”" de hesaba katacak kadar kapsamlı değildir. Bu yüzden mevcut etnik girişimcilik teorilerinin çoğunun "expat-preneurs" gibi bir olguya yer açmak için genişletilmesine ihtiyaç duyulmaktadır. Bu çalışma çok fazla araştırılmamış bir olgu olan "Kendi isteğiyle göç eden girişimciler" konusu çerçevesinde ilgili literatürdeki boşluğa katkı sağlamaktadır (Andresen vd., 2014).

Anahtar Sözcükler $\quad$ : Gurbetçi Girişimciler, Kendi İradesiyle Göç Eden Girişimciler, Etnik Girişimciler, Göçmen Girişimciler, Etnik Girişimcilik, Hayat Tarzının Göçü, İçiçe Geçmişlik.

\section{Introduction}

In terms of migration, people are more likely to migrate to a more economically developed country than the country they leave behind. This is illustrated by the fact that global South - North migration in 2015 was 85.3 million, whereas North - South migration in the same year was only 13.6 million (UN DESA, 2015). It is no surprise, therefore, that in the context of entrepreneurship and migration, the overwhelming majority of studies have focused on migrants who have moved in this direction. This demographic is usually referred to in the literature as "ethnic entrepreneurs" (Waldinger et al., 1990) or "immigrant entrepreneurs" (Volery, 2007). A large amount of research has been conducted around this phenomenon, often with the goal of accounting for the high rates or ethnic entrepreneurship and the success/failure rates of such enterprises. This has given rise to several theories, such as Disadvantage Theory (Aurand, 1983; Light \& Rosenstein, 1995), Cultural Approach (Masurel, 2004), and Mixed-Embeddedness Theory (Kloosterman \& Rath, 1999) among others. More recently, a new trend is emerging: A small (but potentially significant) number of people are emigrating away from developed economies and starting their own businesses abroad. These migrants have been labelled as "expat-preneurs" (Vance et al., 2016) or "Self Initiated Expatriate entrepreneurs" (Andresen, 2014) and are differentiated from ethnic entrepreneurs on the basis of three qualities: 1. Expat-preneurs choose to become entrepreneurs out of volition, not necessity (Vance et al., 2016); 2. Expat-preneurs do not intend to stay permanently in the host country (Vance et al., 2016); 3. Expat-preneurs' are 
coming from a position of privilege (usually a developed economy). The emerging trend of expat-preneurs poses several questions (and problems) for the existing theories surrounding ethnic entrepreneurs: Where do expat-preneurs fit into the theoretical landscape? Can the theories - created to account for ethnic entrepreneurs - also explain the behavior of expatpreneurs?

The objective of this paper is to answer these questions by reviewing eight of the existing ethnic entrepreneur theories against the context of expat-preneurs.

Furthermore, it contributes to the gap in the literature surrounding Self-InitiatedExpatriate (SIE) entrepreneurs, which has been described as an an under-researched phenomenon (Andresen et al., 2014).

\section{Definitions}

The term "expat-preneur" (Solimine, 2015) has been defined as "an individual temporarily living abroad who initiates an international new venture (self-employment) opportunity in a host country" (Vance et al. 2015). Vance et al. differentiate them from ethnic entrepreneurs in two main ways: Firstly, expat-preneurs do not intend to permanently stay in the host country, whereas ethnic entrepreneurs do. Secondly, expat-preneurs are not "necessity entrepreneurs". In other words, they become entrepreneurs out of volition, not necessity. For the purposes of this paper, the authors would like to add a third qualification: Expat-preneurs come from a position of privilege (usually a developed economy). This third differentiation provides a useful structural backdrop which helps to explain the first two. Put simply, because expat-preneurs are coming from a position of privilege, they are not forced by circumstances to remain in the host country, nor forced to open their own business, but instead do so at their own free will.

Ethnic entrepreneurship, by contrast refers to the creation of business(es) by a minority group within a host country, whereby the minority group share a 'common national background or migration experiences' (Waldinger et al., 1990). Sometimes the term 'immigrant entrepreneurs' is also used, usually to denote those who have more recently immigrated or who are first generation immigrants (Volery, 2007).

\section{Materials and Methods}

In order to evaluate if the existing ethnic entrepreneur theories can accommodate the emerging trend of expat-preneurs, the first step was to choose the theories in question. With a couple of exceptions, the authors decided to use the typology of theories assembled by Ilhan-Nas et al. (2011). In their comprehensive review of international ethnic entrepreneurship, Ilhan-Nas et al. provided a 'ready-made' list of all the major theories in this field, albeit missing "Middleman Minority Theory", which has been added to the list for the purposes of this paper. The subsequent list of theories selected was as follows: 
- Disadvantage Theory

- Cultural Approach

- Middleman Minority Theory

- Interactive Model

- Mixed Embeddedness Theory

- Social Network Theory

- Ethnic Enclave Theory

- Schumpeter's Theory

In terms of reviewing these theories against the context of expat-preneurs, content analysis was determined to be the most appropriate method. Content analysis "seeks to analyze data within a specific context in view of the meanings someone - a group or a culture - attributes to them" (Krippendorf, 1989: 403). There are, of course, several forms of content analysis and the choice of the exact approach depends upon the research goals of the researcher and the problem in question (Weber, 1990). For the specific goals of this paper, a non-traditional form of content analysis was selected. Traditional content analysis is based upon a definitive selection of data (often texts), whereas this paper instead analyzes the generic meanings and assumptions of the theories themselves. In other words, the data set is the semantic content of the theories themselves, not a set list of texts.

Content analysis of the theories makes it possible to categorize them according to certain themes or qualities (Milne \& Adler, 1999), enabling us to identify differences between them. These themes were selected by the authors of this paper and, therefore, are a form of deductive coding, as they have been generated prior to the analysis, not during (Joffe \& Yardley, 2004). The theories were codified according to the following four questions:

1. How does the theory account for the entrepreneurial success (or failure) of ethnic minorities?

2. Is the theory set in the context of traditional migration moving from developing economies to developed economies?

3. Does the theory assume that ethnic-entrepreneurs are at a disadvantage?

4. Can the theory also account for the success of expat-preneurs?

It should be noted that question 1 is an open question, whereas questions 2-4 are closed. These questions help to evaluate the universality of the theories. In other words, to what extent the current theories are too narrow - focusing exclusively on ethnic entrepreneurs - or if they are broad enough to also explain the phenomenon of expatpreneurs. 


\section{Findings - Summary}

The main finding was that all eight theories were created in the context of migration to developed economies (usually from developing economies). Subsequently, most of the theories are not - in their current state - broad enough to also account for expat-preneurs. Five out of eight of the theories assume that ethnic entrepreneurs are disadvantaged, whereas expat-preneurs are not considered to be disadvantaged (they typically have high levels of education, (Marchant \& Mottiar, 2011), have created their own business out of volition, not necessity (Vance et al., 2016), and are coming from a position of privilege). One of the theories (Disadvantage Theory - which states that immigrants become entrepreneurs out of necessity) is so narrow that it is completely at odds with expat-preneurs, because - by definition - expat-preneurs do not become entrepreneurs out of necessity.

Table: 1

Content Analysis of Pre-existing Theories

\begin{tabular}{|c|c|c|c|c|}
\hline & $\begin{array}{l}\text { How does it account for the entrepreneurial } \\
\text { success (or failure) of ethnic minorities? }\end{array}$ & $\begin{array}{l}\text { In the context of } \\
\text { South-North } \\
\text { migration? }\end{array}$ & $\begin{array}{l}\text { Assumes immigrant } \\
\text { entrepreneurs are at a } \\
\text { disadvantage? }\end{array}$ & $\begin{array}{l}\text { Can it account for } \\
\text { the success of } \\
\text { expat-preneurs? }\end{array}$ \\
\hline $\begin{array}{l}\text { Disadvantage } \\
\text { theory }\end{array}$ & $\begin{array}{l}\text { The theory that ethnic minorities are forced } \\
\text { into entrepreneurialism as a result of a lack of } \\
\text { better employment opportunities. }\end{array}$ & Yes. & Yes. & No. \\
\hline $\begin{array}{l}\text { Cultural } \\
\text { Approach }\end{array}$ & $\begin{array}{l}\text { Shared cultural traits explain the level of ethnic } \\
\text { entrepreneurial success. }\end{array}$ & Yes. & No. & Potentially. \\
\hline $\begin{array}{l}\text { Middleman } \\
\text { Minority Theory }\end{array}$ & $\begin{array}{l}\text { Being a link between source and host } \\
\text { countries, the 'middleman' is in a good } \\
\text { position to supply the host country with } \\
\text { products from the source country. }\end{array}$ & Yes. & No. & Yes. \\
\hline Interactive Model & $\begin{array}{l}\text { The relationship between shared cultural traits, } \\
\text { the opportunity structure, plus the strategies } \\
\text { ethnic minorities use to access these } \\
\text { opportunities. }\end{array}$ & Yes. & Yes. & Potentially. \\
\hline $\begin{array}{l}\text { Mixed } \\
\text { Embeddedness } \\
\text { Theory }\end{array}$ & $\begin{array}{l}\text { Interactive Model plus the effect of host } \\
\text { country government actions. }\end{array}$ & Yes. & Yes. & Potentially. \\
\hline $\begin{array}{l}\text { Social Network } \\
\text { Theory }\end{array}$ & $\begin{array}{l}\text { Social networks determine the success or } \\
\text { failure. }\end{array}$ & Yes. & Yes. & Potentially. \\
\hline $\begin{array}{l}\text { Ethnic Enclave } \\
\text { Theory }\end{array}$ & $\begin{array}{l}\text { A geographically concentrated group of an } \\
\text { ethnic group which provides cheap labor to } \\
\text { ethnic entrepreneurs in return for employment } \\
\text { and training. }\end{array}$ & Yes. & Yes. & Potentially. \\
\hline $\begin{array}{l}\text { Schumpeter's } \\
\text { Theory }\end{array}$ & $\begin{array}{l}\text { The willingness of ethnic entrepreneurs to take } \\
\text { risk in the pursuit of profit. }\end{array}$ & Yes. & No. & Potentially. \\
\hline
\end{tabular}

However, the other seven theories can potentially be adapted to accommodate expatpreneurs. Taking the Cultural Approach as an example, if it is found that expat-preneurs share certain characteristics (such as a willingness to take risks, or have a hard work ethic), then then this theory may then be applicable to expat-preneurs. Likewise, it may be possible 
for Social Network Theory to be extended from a national to an international level (to account for expat-preneurs utilizing their social networks in their source countries). The other theories can similarly be adapted to broaden them, 'making room' for the phenomenon of expat-preneurs.

\section{Figure: 1}

\section{Content Analysis of Pre-existing Theories}

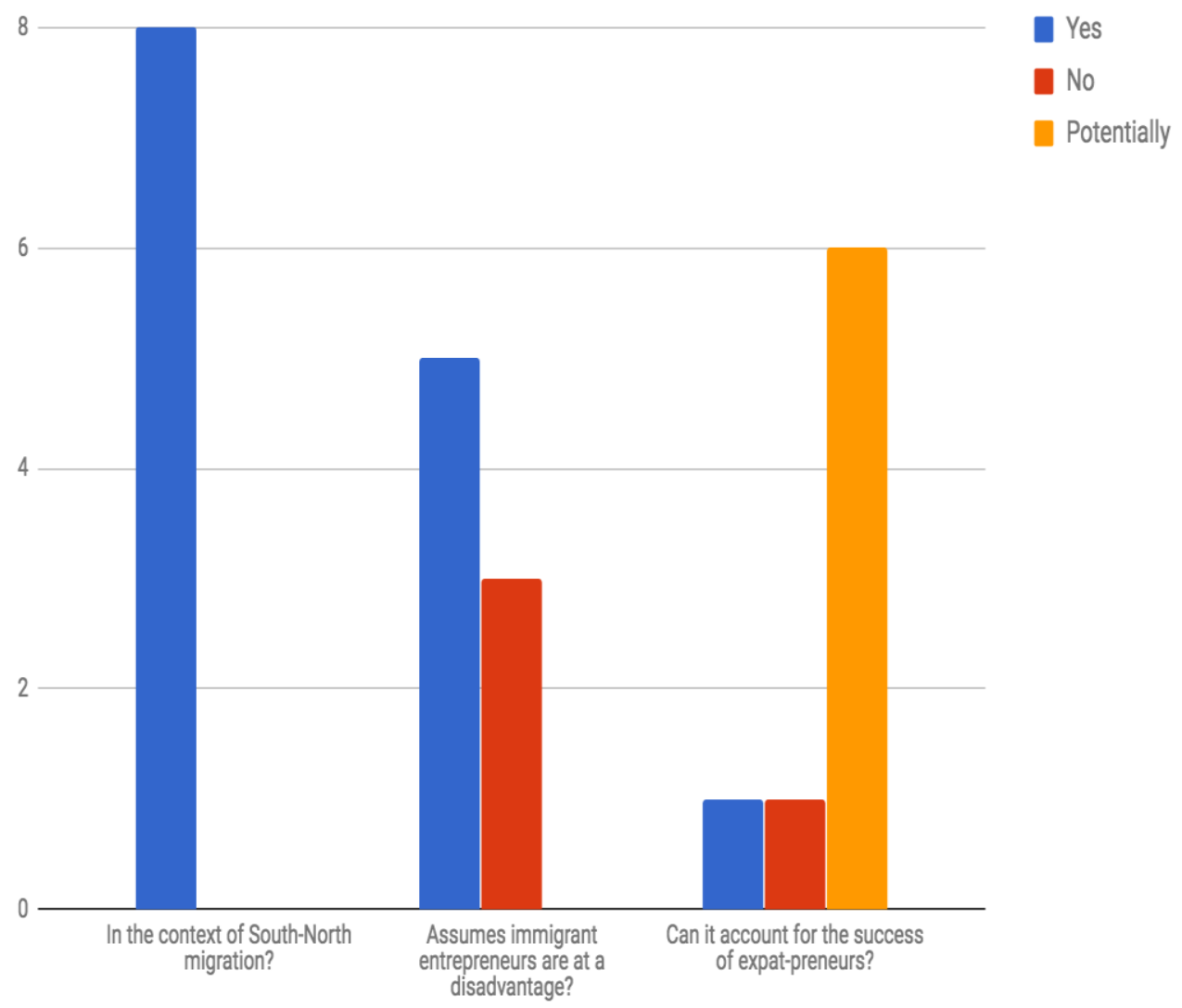

Source: Created by the authors using data from this study.

\section{Findinds -Detailed}

\section{Disadvantage Theory}

Disadvantage Theory is the idea that unemployed people, having failed at finding regular employment, turn to self-employment as a last resort (Aurand, 1983). In terms of ethnic entrepreneurs, it assumes that ethnic minority groups are - as the name suggests 'disadvantaged', which can be a result of education levels, language skills, social and 
financial capital, as well as other factors. In this context, Disadvantage Theory helps to explain the high percentage of ethnic minorities who start their own businesses (Light \& Rosenstein, 1995). Light \& Rosenstein discuss this theory in terms of ethnic minorities in the USA, in other words, in the context of people who have migrated to an economically developed country. Other authors who reference the theory also usually do so in the context of migration to economically developed countries, for example Johnson's paper about Southeast Asian refugees in Canada, (Johnson, 2000).

The theory can only explain the behavior of ethnic entrepreneurs and not that of expat-entrepreneurs. This is because - by definition - it assumes that immigrants are disadvantaged. Expat-preneurs, by contrast, are not disadvantaged. For example, in a study of expat-preneurs on the West Coast of Ireland, found that many of them had high levels of education (Marchant \& Mottiar, 2011). Most importantly, unlike ethnic entrepreneurs, expat-preneurs start their business out of volition, not necessity (Vance et al., 2015). In other words, due to expat-preneurs coming from a position of privilege, they are not disadvantaged, and subsequently the Disadvantage Theory is not applicable. This reveals how narrow the theory is and its shortcomings in terms of its ability to universally account for the behavior of all types of immigrant entrepreneur.

\section{Cultural Approach}

The Cultural Approach is the idea that shared cultural traits can explain why certain ethnic minority groups have high rates of entrepreneurialism. Max Weber observed as long ago as the early 19th Century that certain immigrant groups (he refers namely to the Jewish ethnic minority in Europe) showed more entrepreneurial traits than the mainstream population (Weber, 1905 \& 1930). Such cultural traits could potentially include a strong work ethic, tolerance of risk, the ability to live with low expenses, among others (Volery, 2007). Some studies have supported this theory. For example, Masurel et al's study of Moroccan, Turkish, and Indian/Pakistani ethnic entrepreneurs in Amsterdam, which found differences in success rates and behaviour, concluding that there are some traits specific to each culture which affect economic performance and success (Masurel et. al, 2004).

However, Masurel's study is in the context of migration to countries with developed economies, in other words, in the context of ethnic entrepreneurs, not expat-preneurs. It would be interesting to explore if the theory could also be applied to expat-preneurs. Do expat-preneurs share certain cultural traits which lead to high rates of entrepreneurialism and success/failure rates? There is a lack of research to conclusively answer this, although the study of expat-preneurs on the West Coast of Ireland found that many of them shared the personality trait of being sociable (Marchant \& Mottiar, 2011). Therefore, although the large majority of the literature has so far only applied the theory to ethnic entrepreneurs, it appears to pass the test of 'universality', as it can be extended to the phenomenon of expat-preneurs. However, as a side note, it should be pointed out that, even among studies of ethnic entrepreneurs the theory has not always been supported. For example, Min's study in 1993 which compared Korean immigrants in Japan vs. the USA. Despite both sets of immigrants originating from the same culture (Korea), higher rates on entrepreneurship were found in 
the USA (Min, 1993). This suggests that shared cultural traits are not the dominant factor determining entrepreneurship and instead suggests that factors within the host country are stronger determinants.

\section{Middleman Minority Theory}

The 'Middleman Theory' helped to explain the middleman minorities of the early 19th Century, such as the Jews in Europe, the Chinese in Southeast Asia (Light \& Gold, 2000) and the Japanese on the West Coast of the USA (Bonacich \& Modell, 1980). As 'middlemen' - a bridge between two cultures - they had the necessary language, networks, and skills which lead to high rates of entrepreneurialism (Light in Dana et. al 2008). However, this was is once again in context of migration to countries with developed economies (e.g. Jews in Europe and Japanese on the West Coast of the USA).

Unlike Disadvantage Theory, Middleman Minority Theory assumes that the minority group has an advantage. This makes the theory equally applicable to expat-preneurs, who coming from a position of privilege - are indeed advantaged. The theory, owing to the fact that it positions a minority group as a bridge between two or more cultures, is also able to account for the (expected) transnational nature of expat-preneurs. Expat-preneurs, by Vance et al.'s definition, do not intend to stay permanently in the host country (Vance et al., 2016). It is expected, therefore, that they are less likely to integrate and assimilate (as is the case of middleman minorities), leading to them retaining strong connections with their source country. As such, the Middleman Minority Theory seems very relevant to the phenomenon of expat-preneurs. However, Portes has pointed out that one main difference between traditional middleman minorities and modern transnational expat-preneurs is that the latter is more common and endemic, whereas the former was more exceptional and rate (Portes, 1999).

\section{Interactive Model}

This model describes the relationship between shared cultural traits, the opportunity structure, plus the strategies ethnic minorities use to access these opportunities (Waldinger et al, 1990). It represented significant progress in terms of explaining the behavior of ethnic entrepreneurs, previous theories (e.g. Cultural Approach) had focused more upon the agent, and not the structure. The Interactive Model, by contrast, incorporates both agency and structure. However, once again, the model is in the context of migration to developed economies. For example, the authors of the model discuss it in the context of "Cuban refugees in Miami”, Chinese and Korean immigration to the USA (Waldinger et al, 1990). Furthermore, it somewhat assumes that ethnic minorities are disadvantaged in the host country. For example, Waldinger et al. state that "immigrant minorities must gain access to businesses, and non-ethnic groups' members often control such access" (Waldinger et al., 1990: 114). Not only does the theory assume they are disadvantaged, but it also assumes that immigrant entrepreneurs' business market is in the host country. This ignores that expected transnational component of expat-preneurs. As mentioned previously, due to the fact that expat-preneurs do not intend on staying the host country, plus due to the fact that they have 
access to a developed economy (their host country), it is expected that they are more likely to sell products or services to their source country. As such, in order to account for not just ethnic entrepreneurs, but also expat-preneurs, the Interactive Model would need to be extended to opportunity structures on an international level, and not just a host country level.

\section{Mixed-embeddedness Theory}

Mixed-embeddedness Theory (Kloosterman \& Rath, 1999) is an extension of the Interactive Model, but includes the influence of government action (and inaction) as part of the opportunity structure. Originating from the Netherlands, where there is traditionally more government involvement than in the USA, it is easy to understand why Kloostermann and Rath thought that the effect of government had not been sufficiently accounted for in the Interactive Model. The theory was explained in the context of Turkish and Moroccan ethnic-entrepreneurs in Amsterdam, which is once again in the context of migration to a developed economy. It also, once again, assumes that the immigrants are somewhat disadvantaged. Importantly, as with the Interactive Model, the theory assumes that the opportunity structure only exists within the host country. Specifically, it talks about the effect of "indigenous institutions" upon the entrepreneurial activities of immigrant entrepreneurs. As such, it once again ignores that (expected) transnational element of expatpreneurs. Subsequently, the theory - in its current form - is likely not able to account for the behavior of expat-preneurs. However, it could easily be adapted to redefine the opportunity structure to an international level, which would then make it more applicable to the phenomenon of expat-preneurs.

\section{Social Network Theory}

Social network theory suggests that the success of ethnic entrepreneurs is largely a result of social networks. The logic behind this is that being an entrepreneur is a social role ((Aldrich \& Zimmer, 1986). Aldrich and Zimmer discuss this in the context of Chinese and Japanese immigration in the USA, Cubans in Miami, and Dominicans in New York. Therefore, this is once again through the prism of traditional migration to an economically developed country. Furthermore, the discussions revolve around social networks within the host country with little or no reference to the social networks in the source country. Therefore, once again, this theory seems to only explain the behavior of ethnic entrepreneurs and not that of expat-preneurs. However, the theory could easily be extended to account for expat-preneurs by redefining social networks to an international level, instead of just within the host country.

\section{Ethnic Enclave Theory}

The ethnic enclave theory aims to account for the groups of geographically concentrated ethnic minorities. It explains the high rate of ethnic entrepreneurship through the enclave's provision of cheap labor to ethnic entrepreneurs in return for employment and training (Wilson \& Portes, 1980). Light et al (1994) point out that this is in essence a form of dual labor, whereby ethnic entrepreneurs have access to cheaper labor than other 
entrepreneurs in the mainstream economy. This, therefore, gives them an economic advantage, helping to explain the high incidence of entrepreneurship in such communities. It also means that this theory does not assume ethnic entrepreneurs are disadvantaged. However, as with most of the other theories, it has only been applied to the context of migration to economically developed countries.

Due to a lack of studies, it is not yet apparent if ethnic enclaves also appear among expat-preneurs. However, assuming that expats earn on average higher wages than native labor in the host economy, it would be somewhat economically illogical for expat-preneurs to higher such expensive labor when more affordable local labor is available. This, therefore, suggests that the ethnic enclave theory is not applicable to expat-preneurs.

\section{Schumpeter's Theory}

The classical Schumpeter Theory relies on the importance of agency in the creation and success of entrepreneurial ventures. In his own words "entrepreneurs as individuals who exploit market opportunity through technical and/or organizational innovation" (Schumpeter, 1965). This theory has been disputed even in the context of ethnic entrepreneurs, as it ignores the role of structure (Waldinger et. al, 1990; Kloosterman \& Rath, 1999).

As seen in Table 1, so far it has mainly been discussed in the context of immigrants in developed countries. However, it has the advantage of applicable to expat-preneurs in the sense that it does not assume expat-preneurs are disadvantaged. By contract, it assumes that all entrepreneurs have an advantage, as they have innovative and risk-taking skills which result in their success. There is, however, one potential problem for the application of this theory to expat-preneurs. The theory assumes that entrepreneurs are in pursuit of profit, whereas it seems many expat-preneurs may be lifestyle entrepreneurs, whereby they have emigrated in pursuit of a better lifestyle, not profit, as found in Stone \& Stubbs study of British expat-preneurs in Spain and France (Stone \& Stubbs, 2007).

\section{Discussion}

The emerging trend of expat-preneurs presents a theoretical headache for the existing ethnic entrepreneur theories. The findings highlight how all eight theories selected were created to account for the creation and success of enterprise among ethnic minorities in developed Western economies, not for expat-preneurs leaving these economies. There are likely two reasons for this: Firstly, historically there has been significant immigration in Western economies and limited emigration. Secondly, most of the authors of the theories are from these Western economies and no doubt noticed this trend firsthand (for example, Kloosterman and Rath's Mixed Embeddedness Theory, developed in the context of Turkish and Moroccan entrepreneurs in their home city of Amsterdam (Kloosterman \& Rath, 1999)). Nonetheless, even though expat-preneurs have been less studied, it does not mean they are less important or significant. This emerging phenomenon creates several questions around the existing theories, with some of them fairing better than others. For example, 
Disadvantage Theory is completely redundant in the context of expat-preneurs, because it assumes that expat-preneurs are disadvantaged. However, by definition, expat-preneurs have migrated and become entrepreneurs out of volition, not necessity (Vance et al. 2015), plus have come from a position of privilege, meaning they are not disadvantaged. By contrast, other theories fair much better, and can be extended to account for expat-preneurs. For example, Middleman Minority Theory lends itself very well to this phenomenon, as it may explain why expat-preneurs do not assimilate, have an advantage, and are somewhat transnational.

This aspect of transnationalism is largely ignored by the other seven theories, which explain ethnic entrepreneurialism in the context of traditional migration to economically developed countries. Are expat-preneurs inherently more transnational? After all, by Vance et al.'s (2016) definition, they do not intend on staying in the host country, so does that mean they consequently maintain stronger ties to their source country? Furthermore, assuming expat-preneurs' source country is a developed economy, is their business more likely to make use of the financial capital, social capital, and social networks available there? If expatpreneurs are indeed more transnational than ethnic entrepreneurs, then this has major implications for several of the current theories. For example, the Interactive Model refers to the opportunity structure of the host country. If expat-preneurs are more transnational (for example, selling products or services back to their source country), then the Interactive Model would have to be extended to include the international opportunity structure. Similarly, Mixed Embeddedness Theory - which extends the Interactive Model to include host country government action (and inaction) - would also have to be extended to include the government of the source country. But left in their current state, these theories are too narrow to accommodate expat-preneurs (assuming that expat-preneurs are indeed more transnational).

Although some recent progress has been made in terms of studies about expatpreneurs (Vance et al., 2016; Stone \& Stubbs, 2007; Marchant \& Mottiar, 2011), as well as progress with transnational entrepreneurs (Portes et al., 1999; Saxenien, 2002; Light, 2007) there is still a lack of studies in this field, as noted by Andresen (2015). In particular, there seems to be a lack of theoretical context for the phenomenon of expat-preneurs. As seen in this paper, the existing theoretical landscape was created for ethnic entrepreneurs, not for expat-preneurs. The emerging trend of expat-preneurs brings with it a need to either adjust the current theories to accommodate this new phenomenon, or to create new theories, ideally which can universally explain the behavior of all forms of immigrant entrepreneurialism, whether it be ethnic entrepreneurs or expat-preneurs.

\section{Conclusions}

Ethnic entrepreneurs have been studied extensively and within the last few decades many theories have been formulated to explain this phenomenon. What has been studied far less is the emerging trend of expat-preneurs. The latter is differentiated from ethnic entrepreneurs on the basis of three qualities: 1. Expat-preneurs choose to become entrepreneurs out of volition, not necessity (Vance et al., 2016); 2. Expat-preneurs do not 
intend to stay permanently in the host country (Vance et al., 2016); 3. Expat-preneurs are coming from a position of privilege (usually a developed economy). This emerging trend has created a theoretical headache for the existing ethnic entrepreneur theories, which were all created in the context of 'South to North' migration, with many of them assuming that (all) immigrant entrepreneurs are disadvantaged. As a result, most of the theories are not in their current state - broad enough to also account for expat-preneurs. Subsequently, most of the existing ethnic entrepreneur theories now need to be broadened or adapted to 'make room' for the phenomenon of expat-preneurs. This paper contributes to the gap in the literature surrounding expat-preneurs, which has been described as an ander-researched phenomenon (Andresen et al., 2014).

\section{References}

Aldrich, H. \& C. Zimmer (1986), "Entrepreneurship through social networks", in: D. Sexton \& R. Smiler (eds.), The Art and Science of Entrepreneurship, New York: Ballinger, 3-23.

Andresen, M. et al. (2013), Self-Initiated Expatriation - Individual, Organizational, and National Perspectives, Routledge Studies in International Business and the World Economy.

Autrand, H.W. (1983), "Self-Employment Last Resort of the Unemployed”, International Social Science Review, 58, 7-11.

Blackwood, T. \& G. Mowl (2000), "Expatriate-Owned Small Businesses: Measuring and Accounting for Success”, International Small Business Journal, 18(3), 60-73, doi:10.1177/0266242600183004

Bonacich, E. \& J. Modell (1980), The Economic Basis of Ethnic Solidarity: Small Business in the Japanese American Community, University of California.

Dana, L.P. (2007), Handbook of Research on Ethnic Minority Entrepreneurship: A Co-Evolutionary View on Resource Management, Edward Elgar.

Ilhan-Nas, T. et al. (2011), "International Ethnic Entrepreneurship: Antecedents, Outcomes and Environmental Context", International Business Review, 20(6), 614-626, doi:10.1016/j.ibusrev.2011.02.011

Kloosterman, R. et al. (1999), "Mixed Embeddedness: (In) Formal Economic Activities and Immigrant Businesses in the Netherlands", International Journal of Urban and Regional Research, 23(2), 252-266, doi:10.1111/1468-2427.00194

Krippendorff, K. \& R.P. Weber (1987), "Basic Content Analysis", Journal of the American Statistical Association, 82(397), 354-355, doi:10.2307/2289192

Light, I. et al. (1994), "Beyond the Ethnic Enclave Economy”, Social Problems, 41(1), 65-80, doi:10.1525/sp.1994.41.1.03x0425i

Light, I.H. \& S.J. Gold (2000), Ethnic Economies, Academic.

Light, I.H. \& P. Bhachu (2004), Immigration and Entrepreneurship: Culture, Capital, and Ethnic Networks, Transaction Publishers.

Light, I. \& Leo-Paul Dana (2013), "Boundaries of Social Capital in Entrepreneurship", Entrepreneurship Theory and Practice, 37(3), 603-624.

Marchant, B. \& Z. Mottiar (2011), "Understanding Lifestyle Entrepreneurs and Digging beneath the Issue of Profits: Profiling Surf Tourism Lifestyle Entrepreneurs in Ireland", Tourism Planning \&amp; Development, 8(2), 171-183, doi:10.1080/21568316.2011.573917 
Marks, D.F. \& L. Yardley (2004), “Content and Thematic Analysis”, in: Research Methods for Clinical and Health Psychology, 56-68., doi:10.4135/9781849209793.n4

Masurel, E. et al. (2002), "Motivations and Performance Conditions for Ethnic Entrepreneurship", Growth and Change, 33(2), 238-260, doi:10.1111/0017-4815.00189

Milne, M.J. \& R.W. Adler (1999), "Exploring the Reliability of Social and Environmental Disclosures Content Analysis", Accounting, Auditing \&amp; Accountability Journal, 12(2), 237-256, doi:10.1108/09513579910270138

Portes, A. et al. (1999), “The Study of Transnationalism: Pitfalls and Promise of an Emergent Research Field", Ethnic and Ratial Studies, 22(2), 217-237.

Saxenian, A. (2002), "Silicon Valley's New Immigrant High-Growth Entrepreneurs", Economic Development Quarterly, 16(1), 20-31, doi:10.1177/0891242402016001003

Schumpeter, J. (1961), "Theorie Der Wirtschaftlichen Entwicklung”, in: Joseph Alois Schumpeter The European Heritage in Economics and the Social Sciences, Oxford University Press, 5-59., doi:10.1007/0-306-48082-4_2

Solimine, K. (2015), “The Rise of the 'Expat-Preneur'”, The Wall Street Journal, Dow Jones \&amp; Company, 30 Mar., <blogs.wsj.com/expat/2015/03/30/the-rise-of-the-expat-preneur/>, 28.01.2018.

Stone, I. \& C. Stubbs (2007), "Enterprising Expatriates: Lifestyle Migration and Entrepreneurship in Rural Southern Europe", Entrepreneurship \&amp; Regional Development, 19(5), 433450, doi:10.1080/08985620701552389

Vance, C.M. et al. (2016), “The Expat-Preneur: Conceptualizing a Growing International Career Phenomenon", Journal of Global Mobility: The Home of Expatriate Management Research, 4(2), 202-224, doi:10.1108/jgm-11-2015-0055

Waldinger, R. et al. (1990), Ethnic Entrepreneurs: Immigrant Business in Industrial Societies. Sage.

Weber, M. (2005 [1930]), The Protestant Ethic and the Spirit of Capitalism, Routledge.

Weber, R. (1990), Basic Content Analysis, SAGE Publications, doi:10.4135/9781412983488.

Wilson, K. \& A. Portes (1980), "Immigrant Enclaves: An Analysis of the Labor Market Experiences of Cubans in Miami", American Journal of Sociology, 86(2), 295-319, doi: $10.1086 / 227240$

Yoon, In-Jin, et al. (1996), "Race, Ethnicity, and Entrepreneurship in Urban America", Contemporary Sociology, 25(5), 673, doi:10.2307/2077589 
Girling, R.A. \& E. Bamwenda (2018), “The Emerging Trend of 'Expat-preneurs': A Headache for the Pre-existing Ethnic Entrepreneur Theories”, Sosyoekonomi, Vol. 26(38), 207-219. 